\title{
THE HUMAN RESOURCES AS AN IMPORTANT FACTOR OF REGIONAL DEVELOPMENT
}

\author{
Dana Jašková \\ Alexander Dubček University of Trenčin \\ Katarína Havierniková \\ Alexander Dubček University of Trenčin
}

\begin{abstract}
The human resources present the key aspect of socioeconomic development, prosperity and competitiveness of each region due to the fact that contribute to increasing of employment, to the development of working places and improving the life standard of inhabitants. The main aim of the paper is the quantification of human resources development potential in Slovak regions. To meet this aim, the authors concentrated attention mainly on the evaluation of the level and variability of the selected indicators that were observed within four descriptors. The crucial contribution of the evaluation is the ranking of regions, based on the evaluation in each descriptor and drawing the overall ranking of human resources development potential in the Slovak Republic. To determine the order of regions, the relevant statistical methods were used: the characteristics of location and variability, hierarchical cluster analysis and its method of complete linkage. The results showed the dominance of Bratislava region that is following by Trnava and Žilina region.
\end{abstract}

Keywords: human resources, region, indicator, descriptor.

Received:

Accepted:

\section{INTRODUCTION}

One of the important priorities within the European Union (EU) and thus also in Slovakia is the regional development that shapes the whole growth of socio-economic potential of region. The socio-economic potential of region is the synergy of capital, human resources and natural asset situated in region, resulting in the production of goods and the providing of services. Among the most important factors that contribute to the economic growth belong the labour, capital, and the technical progress, which allows the increasing of the productivity of the first two factors. From the practical regional policy point of view of, Ivanova \& Kordos, (2017) and Kordos \& Krajnakova (2018) argue that this term denotes the targeted and coordinated effort oriented to improving the local socio-economic level and the overall quality of life of the population in the region.

Region by its space represents the product and the frame of human activities. It is the result of natural, technical, educational, public, economic and socio-cultural processes, by which a complex

\footnotetext{
- Corresponding author: Department of Economy and Economics, Faculty of Social and Economic Relations, Alexander Dubček University of Trenčín, Študentská 3, 91150 Trenčín, Slovakia; Tel: +421 327400 429; Email: dana.jaskova@tnuni.sk
} 
is created being connected with internal relations. (Cseh Papp, Varga, Schwarczová, \& Hajós, 2018; Kádár, 2017) Each region is influenced by many heterogeneous factors that contribute to its development: factor of region's location; the factor of territorial-administrative division; factor of the settlement hierarchy; factor of economic development progress; factor of the political situation; localization of enterprises; the factor of foreign direct investment (Fabuš \& Csabay 2018); factor of innovation processes; factor of the specificity of demographic structures and its mobility (Grenčíková, Španková, \& Habánik, 2017; Vlacseková \& Mura, 2017); production factors (Koišová, Masárová, \& Habánik, 2018); quantitative and qualitative characteristics of the population and its movement (Ďurková, Čábyová, \& Vicenová, 2012); research and development (Dul'ová Spišáková, Mura, Gontkovičová, \& Hajduová, 2017) and others. The factor of human resources also belongs to these factors. (Mészáros, 2018; Mura \& Kljucnikov, 2018; Nagy \& Káposzta, 2018). Human resources represent an active factor for further development and differ from other - passive factors. This factor is able to activate and affect the character and intensity of other factors. Regions dispose with a human infrastructure and its systematic development represents the important consideration for policy makers. Many regions produce strategic regional competitiveness in which the development of human resources figures prominently. Over the years, the results of various studies (Grenčíková, et al., 2017; Chocholatá \& Furková, 2018; Jeřábek, 2016; Kádár, 2017; Laskowska \& Dańska-Borsiak, 2016; Oremusova, 2010; Pavel \& Jucu, 2018; Silin \& Tkacheva, 2015; Srovnalíková, Gruzauskas, \& Navickas, 2016; Yussof \& Kasim, 2003) proposed the indicators by which it is possible to assess the level of regional development influenced by human resources from various perspectives.

Due to the stated above, the main aim of this paper was focused on the quantification of human resources development potential in Slovak regions. Following Dufek \& Minařík (2010) we have observed four main descriptors that consist of several indicators. The evaluated descriptors were: Demographic Development, Economic Level and Employment, Social and Living Standards, Health, Education and Crime. Based on the obtained results we set the ranking of Slovak regions in terms of human resources development potential. Based on a Slovak example, this study elaborated the concept of explanation how the quantification of human resources development potential could be realized. The study was based on the specific indicators, not usually used for this type of analysis.

\section{LITERATURE REVIEW}

Kordoš \& Habánik (2018) argue that effective usage of human knowledge, abilities, skills, creativities and other human qualities is the key aspect of each organization success in competitive environment of global economy. Individual person is always the start and the end of all processes (Žul'ová, Švec, \& Madleňák, 2018). Human resources, together with know-how, financial resources, infrastructure resources are the strengths that firms can use to figure out and implement their strategies (Monni, Palumbo, \& Tvaronavičienè, 2017). In general, the human resources are considered as the most important asset of organization. People (not organizations) are responsible for new knowledge creation or acquisition form the others, knowledge dissemination, and its implementation in organizational processes and systems (Okreglicka, Lemanska-Majdzik, \& Gorzen-Mitka, 2016, p. 3). According to Výrostová (2010), the human resources are important factor for development not only because they represent the labour supply (important is mainly their qualification level and labour productivity), but as the consumer, they represent the final demand 
and thus influence the production development of different goods and services, social infrastructure and many others.

The human resources play an important role in all areas of human activities, but not each organization has enough human resources available. (Marchevka, 2017). Most researchers consider employees to be organisations' most valuable assets and that there must be policies and activities to ensure a good working environment and to encourage employees to be open minded, creative, assertive, adventurous, and eager to learn. (Sukserm, \& Takahashi, 2011, p.87). In today's turbulent times, organizations face the challenge to meet many complex requirements while at the same time they have to be adopted to ongoing changes. The necessary changes that would allow us to resolve these problems should, first of all, involve a new approach to human resource management (Głód, 2018, p. 731).

Human resources, traditionally known as labour, are vital in order to support and ensure continuous economic growth of region. The importance of human resources for regional development is based on their nature. They are one of the most significant elements of socioeconomic potential, which a territory can provide for the effective regional development. Population is the carrier of socioeconomic activities in the territory and it is their executor and consumer, it affects the development of facilities of the territory, and has influence on evolution and development of the region (Oremusova, 2010). To meet the objective of economic growth in region, two important issues connected with human resources need to be addressed. First, an adequate supply of a work force required by the economy, and second, the quality of human resources being available to ensure its efficient use (Yussof \& Kasim, 2003). Human beings introduce complexity into their social, economic, and technological systems to solve their problems. The driving force of development are the holders of human resources, who by their attitudes, abilities and experience help to activate or brake and unfold the region.

Human resources are considered to be a part of the population (of the region or country) with the necessary physical and intellectual development, professional skills and knowledge being required to work in any sphere of production of material goods and services (Silin \& Tkacheva, 2015). Due to the competitive paradigm of regions, the most important factors for their comparative advantages' formation are the qualified human resources. The human resources qualification usage plays a decisive role in the competitiveness of the regions.

Human resources shape the combination of different qualities of people being acquired within their experience and acquired within the following process of regional development. The important aspect that affect the quality of human resources in case of regional development is the ageing population (Krajňáková, \& Vojtovič, 2017). Intellectual capital and its components (e.g. human or organizational capital) has also positive impact on firm performance (Fiala and Borůvková, 2011). Human resources also affect the entrepreneurship that contribute to the overall regional development (Fabuš, 2018). Thus, the quality of human resources management will determine the success or failure of any development effort (Valickas., Raišienė, \& Arimavičiūtè, 2017), especially concerning industrialization, adopting technical change and global market response (Yussof \& Kasim, 2003). The view of the region on its own human resources helps to identify and understand the range of opportunities that organizations have in the region. 
Human resources are so important in many ways (Hitka, Lorincová, \& Ližbetinová, 2017). Human resources are treated as the most capacious concept with extended space-time and socio-cultural characteristics, additionally containing the hidden features and quality (Silin \& Tkacheva, 2015).

\section{METHODOLOGY}

The data, from which the analysis was obtained, come from the website of the Statistical Office of the Slovak Republic. The selection of indicators was made with regard to the descriptors that are able to describe the development potential of human resources in the regions. A large number of relevant indicators were selected from a total of 21 indicators and were used as indicators in the framework of four aggregated descriptors. The distribution of the indicators in each of the descriptors is presented in a more thorough review. Listed is the abbreviation of the indicator and in parentheses:

- Demographic developments: D1 - Ageing index (\%); D2 - Crude birth rate (per mile \%); D3 - Crude death rate (per mile \%o); D4 - Crude rate of net migration (per mile \%o); D5 Proportion of persons of the productive age (\%); D6 - Population density.

- Economic level and employment: E1 - Registered unemployment rate (\%); E2 - Economic activity rate (\%); E3 - Employment rate 15-64 y. (\%); E4 - Job vacancy rate (\%); E5 Average number of registered job applicant.

- Living and social level: S1 - Regional gross domestic product per capita (at current prices) $(€)$; S2 - Average gross nominal monthly wage $(€)$; S3 - The average gross household income equivalent ( $€ /$ month); S4 - The number of social facilities (per mile \%o); S5 Average monthly level of pensions paid $(€)$;

- Health, education and crime: $\mathrm{H} 1$ - The number of University students; H2 - The number of high school students; H3 - Average percentage of sickness absence; H4 - The number of doctors; H5 - Criminal offences.

When processing the obtained database shall apply relevant statistical methods. As the basic methods were used the characteristics of the location and variability. When broken down into regions to more homogenous national groups in terms of a range of indicators was applied to the analysis of hierarchical cluster analysis, Complete linkage (furthest neighbour) with Euclidean distance. Effect of different level of variability was excluded and the indicators were standardized indicators to the original values.

Weighting and aggregation systems have crucial effect on the outcome of the Composite Indicator $I_{j}^{R P}$ (in general CI). There is not only one proper method. The list of the most common method is in Organisation for Economic Co-operation and Development (2008). The most widely used method of weighting are: Equal weighting method (EW), Principal component analysis (PCA) and Benefit of Doubt method (BOD). The benefit of Doubt Approach is based on the Data Envelopment Analysis (DEA) which is commonly used in production problems. Using BOD (or DEA) as weighting method is elaborated in Cherchye, Moesen, Rogge, Van Puyenbroeck, Saisana, Saltelli, Liska, and Tarantola (2008). There is not one weighting scheme for all regions. Each region has its own weights, which are optimal for this region. It guarantees the best possible position for 
associated region among all other regions in the sample. Optimal weights in this paper were obtained by solving the following constrained optimization for each region:

$$
I_{j}^{R P}=\max \sum_{i=1}^{n} x_{i j} w_{i}
$$

Subject to $\sum_{i=1}^{n} x_{i j} w_{i} \leq 1, w_{i} \geq 0$.

The development potential quantification of regions and the determination of their ranking was realised by using the PCA analysis, in this paper. The main purpose of PCA is the transformation of the original indicators into a smaller number of latent variables. These are the major components. Their number is smaller and almost all of the original indicators describe the variability. PCA method was used to identify the key indicators and weights assigned to each sub-indicator.

Of its results is the number of analysed indicators scaled. The development potential level of the regions is then expressed by the indices of development potential. In this study, they were constructed on the basis of numerical methods and aggregated according to the relationship:

$$
I_{j}^{R P}=\frac{\sum_{i=1}^{n} b_{i j} w_{i}}{\frac{\sum_{j=1}^{m} \Sigma_{i=1}^{n} b_{i j} w_{i}}{m}}
$$

where: $b_{i i}$ is a point value of $i$-th indicator $i=1, \ldots, n$, and of $\mathrm{j}$-th region; $j=1, \ldots, m, n ; n$ is the number of pointers, $m$ - is the number of regions, $x_{i j}$ je is the original value of $i$-th indicator for $j$-th object, $x_{\max }$ is the maximum value of $i$-th indicator and $x_{\min }$ is the minimum value of $i$-th indicator.

In case of a positive effect, the point value $b_{i j}$ was calculated according to:

$$
b_{i j}=\frac{x_{i j}-x_{\min }}{x_{\max }-x_{\min }}
$$

and in case of a negative scope according to the relationship:

$$
b_{i j}=\frac{x_{\max }-x_{i j}}{x_{\max }-x_{\min }}
$$

The direction of action was designed so that if the increase in value of the indicator was assessed positively, it would be the positive scope of application. Where the indicator value was increased, it was seen as a negative phenomenon. If the index is 1 , it can be said that the development of the region is an average. The rule is that the higher the value of the index, the greater the level of the development potential of the region. In the event that the value of the index is declining, it is also reduced the development potential of the region to be evaluated.

Comparison of the regions we evaluated by using cluster analysis. Cluster analysis is among the methods to deal with the investigation of similarities of multidimensional objects. Clustering is a classification of objects into various clusters so that objects within a cluster are similar as far as possible and with objects from different clusters. The main objectives of the cluster analysis 
include description of the taxonomy, the simplification of the data and identification of relationships.

In the implementation of the cluster analysis we have conducted the following steps in paper (Meloun, \& Militký, 2002):

1. Standardization of selected variables (z-core).

2. The selection criteria on the basis of the calculation method of hierarchical cluster analysis are Cophenetic correlation coefficient (CC), Delta $(0,5)$ and Delta (1). When considering the degree of tightness of the construction dendrogram assurance of transfer. The first criterion in the choice of the "best" dendrogram is value of CC. The second criterion is a criterion that is leak-transfer by Delta $(\Delta)$ measured the degree of changes to the structure of the data rather than the degree of similarity. Delta criterion is defined by formula:

$$
\Delta_{A}=\left[\frac{\sum_{j<k}^{N}\left|d_{j k}-d_{j k}^{*}\right|^{1 / A}}{\sum_{j<k}^{N}\left(d_{j k}^{*}\right)^{1 / A}}\right]^{A}
$$

where $\mathrm{A}=0.5$ or $1, d_{j k}$ is a distance in the original matrix of distances and $d^{*}{ }_{j k}$ indicates the distance obtained from dendrogram. It is desirable that the value $\Delta_{\mathrm{A}}$ were close to zero.

3. The creation of dendrograms. Estimation of the optimal number of clusters.

4. Application non-hierarchical cluster procedures (K-means, Fuzzy clustering).

5. Classification of regions into clusters. Assessing the similarity of objects included in the cluster.

\section{RESULTS AND DISCUSSION}

A basic overview of the characteristics of the location and variability of all indicators provides a Table 1. Characteristics are calculated from the data set of the eight regions in Slovakia. Each region as a unit of the reference of the file has the same weight. There are the basic characteristics of the level and variability of the monitored indicators in the table 1 .

Demographic development indicators influence the Bratislava region's high level of variability of the D6 indicator. The population density is in the capital city, on average, three times more than in other regions. Also, the Crude rate of net migration is highly positive in the Bratislava region. This indicator is positive even in the Trnava region in other regions is negative. About the variability of the median has an Index of aging, all other lights have little variability. 
Table 1: Descriptive statistics of evaluated indicators

\begin{tabular}{|c|c|c|c|c|}
\hline \multirow[t]{2}{*}{ Descriptors } & \multirow[t]{2}{*}{ Indicators } & \multicolumn{3}{|c|}{ Descriptive statistics } \\
\hline & & Average & $\begin{array}{l}\text { Standard } \\
\text { deviation }\end{array}$ & $\begin{array}{l}\text { Coefficient } \\
\text { of variation }\end{array}$ \\
\hline \multirow{6}{*}{ 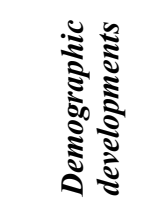 } & D1 - Ageing index & 100.50 & 18.22 & 18.13 \\
\hline & D2 - Crude birth rate & 10.52 & 1.41 & 13.42 \\
\hline & D3 - Crude death rate & 9.71 & 0.93 & 9.59 \\
\hline & D4 - Crude rate of net migration & 0.89 & 3.89 & 437.31 \\
\hline & D5 - Proportion of persons of the productive age & 69.59 & 0.86 & 1.24 \\
\hline & D6 - Population density & 133.02 & 74.88 & 56.29 \\
\hline \multirow{5}{*}{ 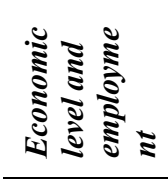 } & E1 - Registered unemployment rate & 8.52 & 3.97 & 46.65 \\
\hline & E2 - Economic activity rate & 60.24 & 3.07 & 5.10 \\
\hline & E3 - Employment rate 15-64 y. & 65.39 & 5.35 & 8.19 \\
\hline & E4 - Job vacancy rate & 0.98 & 0.56 & 57.17 \\
\hline & E5 - Average number of registered job applicant & 4.89 & 2.16 & 44.26 \\
\hline \multirow{5}{*}{ 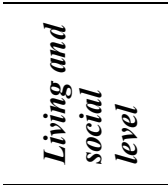 } & S1 - Regional gross domestic product per capita & 15305.59 & 8528.37 & 55.72 \\
\hline & S2 - Average gross nominal monthly wage & 977.88 & 159.61 & 16.32 \\
\hline & S3 - The average gross household income equivalent & 754.18 & 96.00 & 12.73 \\
\hline & S4 - The number of social facilities & 7129.88 & 1366.89 & 19.17 \\
\hline & S5 - Average monthly level of pensions paid & 391.63 & 28.64 & 7.31 \\
\hline \multirow{5}{*}{ 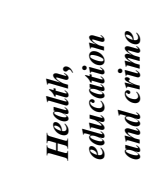 } & H1 - The number of University students & 14011.50 & 11499.16 & 82.07 \\
\hline & H2 - The number of high school students & 21655.88 & 3927.98 & 18.14 \\
\hline & H3 - Average percentage of sickness absence & 3.22 & 0.63 & 19.66 \\
\hline & H4 - The number of doctors & 2437.93 & 654.87 & 26.86 \\
\hline & H5 - Criminal offences & 796.50 & 82.76 & 10.39 \\
\hline
\end{tabular}

Source: own calculation

In case of the Economic Level and Employment Descriptor, employment-related variables are significantly lower than those indicators for unemployment-related. Ever lowest variability is in Economic activity, since it is $5.1 \%$. On the other hand, the highest variability in job vacancies per job applicant is $57.17 \%$. In this case, the highest value was recorded in the Bratislava region.

The capital city of Bratislava has a significantly higher GDP per capita and the average nominal wage of the employee, which also affects the higher variability. In the region of Bratislava, regional GDP is on average $€ 400$ more than in the remaining seven regions. There is a high variability in the evaluated regions even in the number of social facilities.

In case of Health descriptor, education, crime, high variability is shown by H1, which is the Number of university students. This phenomenon is natural, as most schools in Europe are concentrated mostly in capital city. The districts of Bratislava and Košice have approximately doubled the number of doctors per capita. The reason is that there is a higher concentration of top medical facilities in the two largest cities in Slovakia, where the two largest faculties of medicine are situated. 
Figure 1: The dendrograms for each descriptor (Complete linkage)

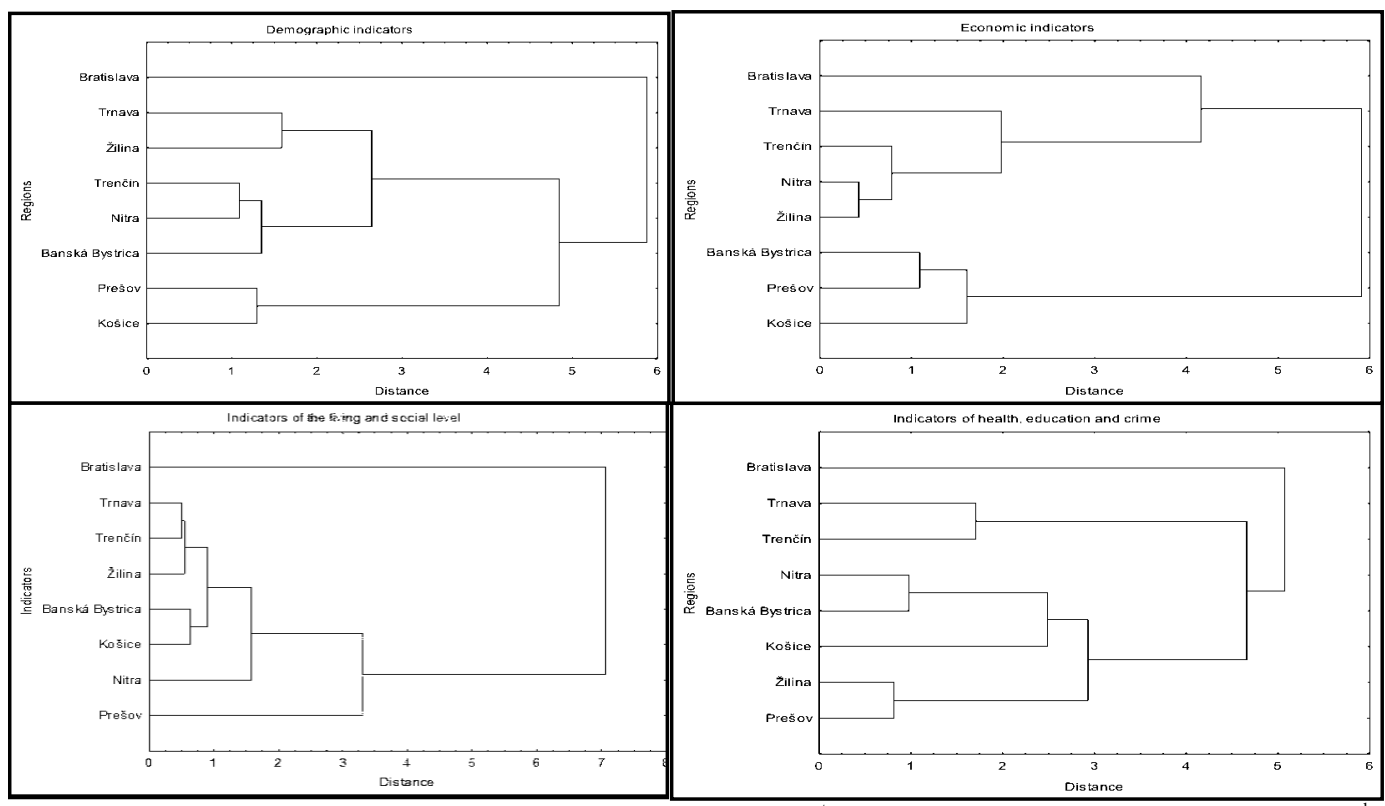

Source: own research, elaborated in program STATISTICA 12 , Notes: $1^{\text {st }}$ dendrogram is linked with indicators D1-D6, $2^{\text {nd }}$ dendrogram is linked with indicators E1-E5, $3^{\text {rd }}$ dendrogram is linked with indicators $\mathrm{S} 1-\mathrm{S} 5,4^{\text {th }}$ dendrogram is linked with indicators $\mathrm{H} 1-\mathrm{H} 5$

For the purposes of analysis of the cluster 21 regional indicators were used, which are described in Table 1. Input data had different variability of different units of measure. All values were converted to the middle state of the population in a given period. Therefore, in the introduction of the analysis the data was standardized by z-score. In the next step we proceeded to choose the most appropriate cluster method. Based on the calculations of the Cophenetic correlation coefficient $\mathrm{CC}=0.93877$, $\Delta 0.5=0.161377$ and $\Delta 1.0=0.203938$, we have determined that the most appropriate hierarchical clustering method is Compete Linkage (Method of furthest neighbour) with Euclidean distance type. The following figure shows dendrograms for each area of descriptors.

From the individual dendrograms, the dominance of the Bratislava region is evident, which forms a separate cluster in all the studied areas. The regions of Košice and Prešov are clustered in almost every area. Disparity with other regions is obvious. Subsequently, one dendrogram was created for all descriptors. Dendrograms were created in Statistica 12 and free available software NCSS 12. 
Figure 2: The dendrograms of all indicators
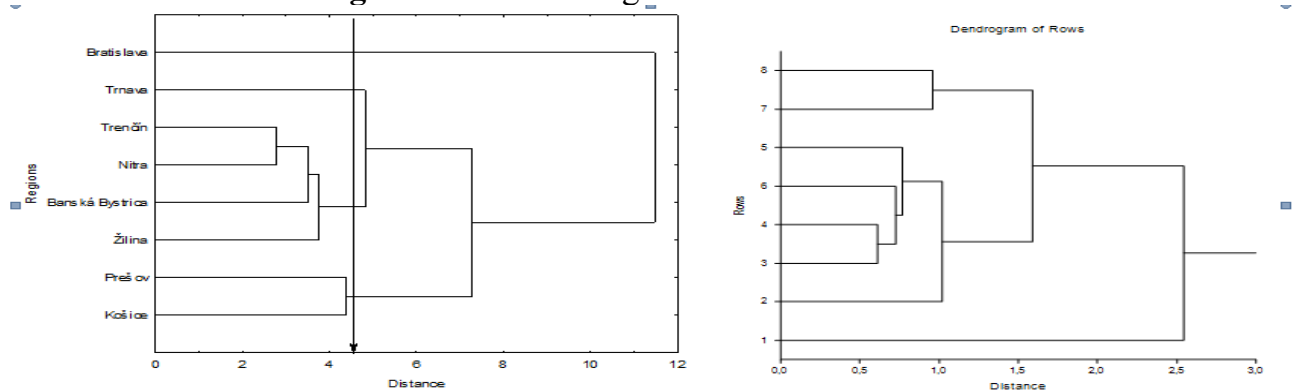

Source: own research, elaborated in program NCSS Statistical Software 12 (https://www.ncss.com/download/ncss/updates)

Hierarchical clustering diagrams are then used to select the optimal number of clusters for nonhierarchical clustering. In both cases, four optimal clusters were indicated. This number was determined to be optimal in subsequent non-hierarchical clustering.

Non-hierarchical clustering methods differ from hierarchical ones to the fact that these methods require information on the input of the number of clusters we will require in the result. They do not create a hierarchical structure; divide the set into subsets according to a pre-selected criterion. The first subset decomposition is not subdivided. It is adjusted to optimize the spacing and diversity of the clusters and to spread the clusters evenly. To find the best breakdown by trying out all the options is very tedious, in some cases not feasible. Therefore, most methods begin by just determining how many clusters we want to convert and then look for optimal decomposition. Optimal decomposition means the best breakdown that is best with respect to that criterion. By optimal decomposition, we gained from the data important insights that are easy to interpret and will give us the information we need. (Wehrens, 2011).

The first method was applied by K-means. This non-hierarchical aggregation method looks for the optimal cluster distribution based on the minimization of the sum of squares error criteria. As we stated and explained above, the result of the clustering process is the following clusters (output of NCSS 12):

1. Cluster: Bratislava

2. Cluster: Trnava, Trenčín

3. Cluster: Nitra, Žilina, Banská Bystrica

4. Cluster: Prešov, Košice.

As the second method was applied by the Fuzzy clustering. The outputs of this cluster are similar to the previous one. The resulting clustering is in the Table 2.

In this case, the Žilina region is included in the cluster along with Trenčín and Trnava. Silhouette plot shows that the regions of Trnava, B. Bystrica, Nitra and Prešov have a long silhouette. This means that they are very well integrated into the cluster. For other objects, there is a certain uncertainty about proper clustering. It is a subjective assessment whether Žilina will be included in the second or third cluster. 
Table 2: Outputs of clustering - the Fuzzy clustering

\begin{tabular}{lcccccc|}
\hline Region & Cluster & $\begin{array}{c}\text { Cluster } \\
\text { Membership }\end{array}$ & $\begin{array}{c}\text { Sum of } \\
\text { Squared } \\
\text { Memberships }\end{array}$ & $\begin{array}{c}\text { Bar of Squared } \\
\text { Memberships }\end{array}$ & $\begin{array}{c}\text { Silhoutte } \\
\text { Amount }\end{array}$ & $\begin{array}{c}\text { Silhoutte } \\
\text { Bar }\end{array}$ \\
\hline Bratislava & 1 & 0.9974 & 0.9949 & $\mid$ IIIIIIIIIIIIIIIIIIIIIIIIIIIIIII & 0.0000 & $\mid$ \\
Trenčín & 2 & 0.6870 & 0.5157 & $\mid$ IIIIIIIIIIIIIII & -0.0038 & $\mid$ \\
Trnava & 2 & 0.5408 & 0.3750 & $\mid$ IIIIIIIIIII & 0.2371 & $\mid$ IIIIIIII \\
Žilina & 2 & 0.3559 & 0.3032 & $\mid$ IIIIIIII & -0.0301 & $\mid$ \\
B. Bystrica & 3 & 0.7160 & 0.5454 & $\mid$ IIIIIIIIIIIIIIIII & 0.2419 & $\mid$ IIIIIIII \\
Nitra & 3 & 0.4322 & 0.3326 & $\mid$ IIIIIIIIII & 0.2001 & $\mid$ IIIIIII \\
Košice & 4 & 0.8969 & 0.8086 & $\mid$ IIIIIIIIIIIIIIIIIIIIIIIII & 0.0062 & $\mid$ \\
Prešov & 4 & 0.3822 & 0.2909 & $\mid$ IIIIIIIIIIIIIIIIIIIIIIIII & 0.2659 & $\mid$ IIIIIIIII \\
\hline \hline
\end{tabular}

Source: own research.

Bar of Squared Memberships is a bar graph of the sum of squared membership values. It will help us to detect rows that are not well clustered. Subsequent to the analysis of the mutual similarity of the regions according to the cluster analysis, it was carried out by Principal component analysis (PCA). Two latent variables were found which, based on eigenvalues, account for $82.32 \%$ of variability. Based on factor load values, the number of indicators in all descriptors was reduced to 12. The D1, D4, D6, E4, S2, S3, S5, H1 and H3 indicators were no longer included in the next analysis. The weights of indicators $w_{\mathrm{i}}$ were calculated within results of PCA analysis, the average for each descriptor is equal to 1 .

Table 3: Weights of indicators

\begin{tabular}{|c|c|c|c|c|c|c|c|c|c|c|c|c|}
\hline Indicator & D2 & D3 & D5 & E1 & E2 & E3 & E5 & S1 & S4 & H2 & H4 & H5 \\
\hline$w_{i}$ & 1.3 & 0.7 & 1.0 & 1.3 & 1.1 & 0.9 & 0.7 & 1.5 & 0.5 & 0.8 & 1.1 & 1.1 \\
\hline
\end{tabular}

Source: own research.

The weighted values of the indicators were included in the calculation of the aggregate indicator $I_{j}^{R P}$ using the point method. Index values $I_{j}^{R P}$ are suitable for mutual comparison of regions and their ranking. If its value equals 1 , it is indicative of the average level of development potential of the region. The region's ranking is based on the difference between the input values of the given indicator and its minimum or maximum value. It takes into account the direction of the indicator. In the same way, by using the point method, the order of the regions was determined by the individual descriptors based on the calculated values of the aggregated sub-indicators. The overview of the sub-indicator values found in comparison between regions is presented in the following figure (3). All descriptors have been assigned the same weight. 
Figure 3: Comparison of sub indicators

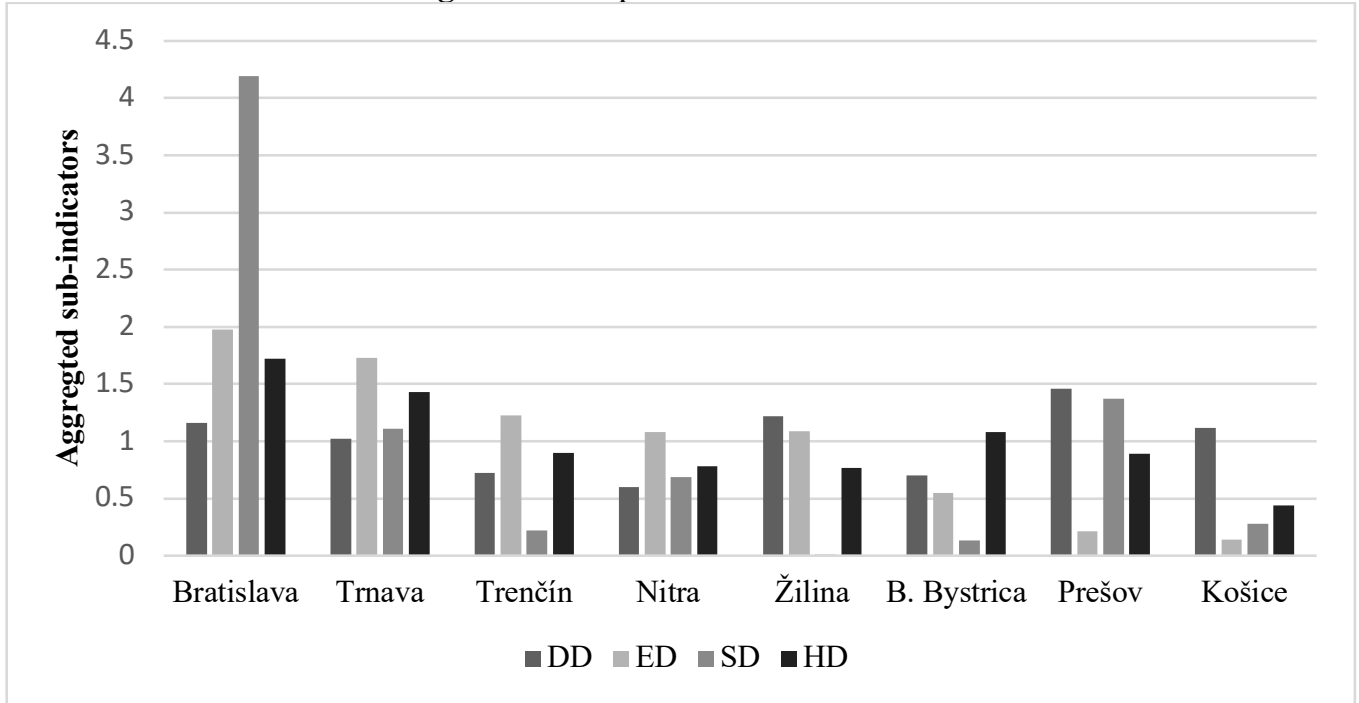

Source: own research. Notes: DD - demographic developments descriptor, ED - Economic level and employment descriptor, SD - Living and social level descriptor, HD - Health, education and crime descriptor

In the figure, for each region, the column height displays the value of the sub-indicator for each region. From the demographic point of view, the Prešov region is the best. From an economic point of view, however, it is one of the worst. The Region of Bratislava in the monitored period of 2016 shows the best results in the economic, social, health, educational and criminal fields.

The following table shows the values of each sub-indicator and the ranking of the region. Subsequently, the calculated value of the gauge indicator is calculated $I_{j}^{R P}$ for each region and overall ranking.

Table 4: The resulting values and the ranking of regions

\begin{tabular}{lcccccccccc}
\hline \multicolumn{1}{c}{ Region } & DD & order & ED & order & SD & order & HD & order & $\begin{array}{c}\text { Aggregated Order } \\
\text { Index }\end{array}$ & overall \\
\hline Bratislava & 1.16 & 3 & 1.98 & 1 & 4.19 & 1 & 1.72 & 1 & $\mathbf{1 . 6 8}$ & $\mathbf{1}$ \\
Trnava & 1.02 & 5 & 1.73 & 2 & 1.11 & 3 & 1.43 & 2 & $\mathbf{1 . 3 0}$ & $\mathbf{2}$ \\
Trenčín & 0.72 & 6 & 1.23 & 3 & 0.22 & 6 & 0.90 & 4 & $\mathbf{0 . 9 1}$ & $\mathbf{4}$ \\
Nitra & 0.60 & 8 & 1.08 & 5 & 0.69 & 4 & 0.78 & 6 & $\mathbf{0 . 8 9}$ & $\mathbf{6}$ \\
Žilina & 1.22 & 2 & 1.09 & 4 & 0.01 & 8 & 0.77 & 7 & $\mathbf{1 . 0 5}$ & $\mathbf{3}$ \\
B. Bystrica & 0.70 & 7 & 0.55 & 6 & 0.13 & 7 & 1.08 & 3 & $\mathbf{0 . 6 7}$ & $\mathbf{7}$ \\
Prešov & 1.46 & 1 & 0.21 & 7 & 1.37 & 2 & 0.89 & 5 & $\mathbf{0 . 9 0}$ & $\mathbf{5}$ \\
Košice & 1.12 & 4 & 0.14 & 8 & 0.28 & 5 & 0.44 & 8 & $\mathbf{0 . 6 0}$ & $\mathbf{8}$ \\
\hline \hline
\end{tabular}

Source: own research. DD - Demographic Descriptor, ED - Economic Descriptor, SD - Social Descriptor, HD - Health Descriptor.

Ranking from the best rated region to the worst is as follows: Region of Bratislava, Trnava, Žilina, Trenčín, Prešov, Nitra, B. Bystrica a Košice. It is interesting to see the Prešov region at 5, instead. 
Probably rated indicators correspond to the significant development potential of this region. Region Bratislava shows an excess value of the monitored index of development potential. The region of Trnava is almost over-averaging. The value $I_{j}^{R P}>1$ still belongs to the Žilina region. These regions are working with automotive clusters. Their functioning is closely related to the existing developed automotive industry. The last place is the Košice region. It is the second largest city in Slovakia. However, it has the worst economic results and also the health, education and crime outcomes.

\section{CONCLUSION}

This paper was focused on the evaluation of development potential of Slovak regions from the point of view of human resources. The output of realized analysis is the determination of the overall ranking of Slovak regions from the point of view of selected indicators. The selection of indicators was realised with regard to the descriptors that are able to describe the development potential of human resources in the regions. This study follows research of Dufek \& Minarík (2010), with the reflection of data availability in Slovak conditions. The Slovak Republic consists of 8 regions at the level of NUTS3, while Czech Republic of 14 regions. The results showed similar situation in case of capital cities. The Capital City Prague occupies the first place within three descriptors, but from the point of view of demographic development up to $8^{\text {th }}$ place. The capital city Bratislava in case of descriptors ED, SD, HD were placed at the first position and in descriptor DD, which described demographic development took $3^{\text {rd }}$ place. The opposite situations were observed in case of region Liberec in Czech Republic and in Slovakia it was region Prešov. While in demographic descriptor, Prešov was placed in $1^{\text {st }}$ place and in the rest of descriptors it took last places.

Descriptors describe the Demographic development, Economic level and employment, Living and social level and Health, education and crime. All indicators were assessed by using the advanced multivariate statistical techniques. Weight was assigned to the indicator by using the PCA analysis. The aggregation of indicators was realized by using the point numerical methods and min-max the standardization. As a first, the aggregate indicator was calculated for each descriptor and, consequently, the calculation of overall indicator was realized. At the first place in development potential of human resources was placed the Bratislava region followed by Trnava and Žilina region. Finally, in frame of this evaluation the Košice region was observed as a region with the lowest development potential of human resources.

For a better understanding of the typologies of the regions, the Cluster analysis was used. Based on the values of the CC coefficients, and $\Delta_{0.5}, \Delta_{1.0}$, a hierarchical clustering Complete linkage method with Euclidean distance type were used. From the resulting dendrograms, being used subsequent nonhierarchically, four clusters sticking together have been revealed by applying the K-means and Fuzzy clustering method. The first cluster was made up by the Bratislava region, which corresponds to the best position in assessing of the regional potential by using the aggregate indicator. There were regions of Košice and Prešov in the fourth cluster. Both regions are characterized by long term slowest socio-economic development in the field of human potential. The State regional policy should be concentrated on developing the activities in these regions. The focus should be oriented to the area in which these regions are lagging behind in the long term. 
The primary focus should be based on the adequate quantitative analysis, but also on the subjective evaluation.

\section{ACKNOWLEDGEMENT}

This paper is a part of the project VEGA 1/0953/16 The evaluation of clusters' impact measurement on regional development of the Slovak Republic as the partial output.

\section{REFERENCES}

Cherchye, L., Moesen, W., Rogge, N., Van Puyenbroeck, T., Saisana, M., Saltelli, A., Liska, R., Tarantola, S. (2008). Creating Composite Indicatiors with DEA and Robustness Analysis: the case of the Technology Achievement Index. Journal of the Operational Research Society, 59, 239-251.

Chocholatá, M., \& Furková, A. (2018). The analysis of employment rates in the context of spatial connectivity of the EU regions. Equilibrium. Quarterly Journal of Economics and Economic Policy, 13(2), 181-213. doi:10.24136/eq.2018.010

Cseh Papp, I., Varga, E., Schwarczová L., Hajós, L. (2018). Public work in an international and Hungarian context. Central European Journal of Labour Law and Personnel Management, 1(1), 6 - 16. doi:10.33382/cejllpm.2018.01.01.

Dufek, J, \& Minařík, B. (2010) Human Resources as important Factor of the development Potential of Regions of the Czech Republic. Retrieved from https://docplayer.cz/16240051Lidske-zdroje-jako-vyznamny-faktor-rozvojoveho-potencialu-kraju-ceske-republiky.html.

Dul'ová Spišáková, E., Mura, L., Gontkovičová, B., Hajduová, Z. (2017). R\&D in the context of Europe 2020 in selected countries. Economic Computation and Economic Cybernetics Studies and Research, 51(4), 243 - 261.

Durková, K., Čábyová, K., \& Vicenová, E. (2012) Regional development in economic core regions. Review of Applied Socio- Economic Research, 4(2), 87-92.

Fabuš, M. (2018) Business Environment Analysis Based on the Global Competitiveness Index (GCI) and Doing Business (DB): Case Study Slovakia. Journal of Security and Sustainability Issues, 7(4), 831-838.

Fabuš, M., \& Csabay, M. (2018). State aid and investment: case of Slovakia. Entrepreneurship and Sustainability Issues, 6(2), 480-488. doi:10.9770/jesi.2018.6.2(1).

Fiala, R., \& Borůvková, J. (2011). Relationship between Organizational Capital and Firm Performance. In Jirčíková, E.. Pastuszková, E. Svoboda, J. (Eds.), Finance and the Performance of Firms in Science, Education, and Practice (pp. 88-95). Zlín: Tomas Bata University in Zlín.

Głód, W. (2018). Transformational leadership style in the relationship between innovation and efficiency of healthcare units in Poland. Oeconomia Copernicana, 9(4), 731-753.

Grenčíková, A., Španková, J., Habánik, J. (2017). Regional Disparities in Labor Force Migration abroad in Slovak Republic and in Czech Republic. Economics and Sociology, 10(3), 81-89.

Hitka, M., Lorincová, S., Ližbetinová, L. (2017). Manager's data in human resource management from the perspective of the work position. Acta Oeconomica Universitatis Selye, 6(2), $69-$ 80 . 
Ivanova, E., \& Kordos, M. (2017). Innovation Policy of SMEs in Slovakia in the context of European Union Innovation Policy. Marketing and Management of Innovations, 3, 213225. doi:10.21272/mmi.2017.3-20.

Jeřábek, Z. (2016). Predispositions of an applicant for an employment - advantage for getting hired and for the length of an employment. Acta Oeconomica Universitatis Selye, 5(1), 73 - 84.

Kádár, B. (2017). Including labour market proposals in higher education offers. Acta Oeconomica Universitatis Selye, 6(2), $89-100$.

Koišová, E., Masárová, J., \& Habánik, J. (2018) Regional Differences in the Labour Market in Slovakia and the Czech Republic. Journal of Competitiveness, 10(2), 104-117.

Kordos, M., \& Krajnakova, E. (2018). Significance of Innovation in Slovak Regions - Issues and Challenges. AD ALTA-Journal of Interdisciplinary Research, 8(1), 137-141.

Kordoš, M., \& Habánik, J. (2018). Corporate culture interplay issues in global economy. Problems and Perspectives in Management, 16(3), 302-310. doi: 10.21511/ppm.16(3).2018.24

Krajňáková, E., \& Vojtovič, S. (2017), Struggles of Older Workers at the Labour Market, Economics and Sociology, 10(1), 319-333. doi: 10.14254/2071- 789X.2017/10-1/23

Laskowska, I., \& Dańska-Borsiak B., (2016). The Importance Of Human Capital For The Economic Development Of EU Regions. Comparative Economic Research, 19(5), 63-79.

Marchevka, M. (2017). The Stockpile Planning System for International Crisis Management. Vojenské reflexie, $12(1), 65-80$.

Meloun, M., \& Militký, J. (2002). Kompendium statistického spracování dat. Praha: Academia.

Mészáros, M. (2018). "Employing" of self-employed persons. Central European Journal of Labour Law and Personnel Management, 1(1), 46 - 67. doi:10.33382/cejllpm.2018.01.04.

Monni, S.; Palumbo, F., \& Tvaronavičienė, M. (2017). Cluster performance: an attempt to evaluate the Lithuanian case. Entrepreneurship and Sustainability Issues, 5(1), 43-57. doi:10.9770/jesi.2017.5.1(4).

Mura, L., \& Kljucnikov, A. (2018). Small Businesses in Rural Tourism and Agrotourism: Study from Slovakia. Economics \& Sociology, 11(3), 286-300.

Nagy, H., \& Káposzta, J. (2018). The Role of Human Resource Development in the Sustainable Development of Hungary. Economics, Management and Financial Markets, 13(3), 173 184.

Organisation for Economic Co-operation and Development (OECD) (2008). Handbook on Constructing Composite Indicator. Methodology and User Guide. Retrieved from https://www.oecd.org/els/soc/handbookonconstructingcompositeindicatorsmethodologyan duserguide.htm

Okreglicka, M., Lemanska-Majdzik, A., \& Gorzen-Mitka, I. (2016). Learing Organizations and Their Adaptability to Market Environment. In J. Stankeviciene, T. Lankauskiene, (Eds.), $9^{\text {th }}$ International Scientific Conference - Business and Management 2016 (pp. 1-8). Vilnius: Vilnius Gediminas Technical Univ Press

Oremusova, D. (2010) Human Resources in the Termal Microregion and Their Importance for Regional Development. Geographia Cassoviensis. 4(2), 147-151.

Pavel, S., \& Jucu, S. (2018). An evaluation of the human resources potential of the Western Region (Romania). Forum Geografic. 17(1), 99-105. doi:10.5775/fg.2017.147.i

Silin A., N., \& Tkacheva, N. A. (2015). Formation of Human Resources in the Process of Circumpolar Region Development. International Journal of Economics and Financial Issues, 5(2), 121-127. 
Srovnalíková, P., Gruzauskas, V., \& Navickas, V. (2016). Technological innovations development impact to the labour market: structural unemployment case. Social and Economic Revue, 14(3), $81-90$.

Sukserm, T., \& Takahashi, Y. (2011). Effects of Individual Characteristics on Learning Through Human Resource Development (HRD) in Corporate Social Responsibility (CSR) Activity. International Journal of Business \& Society, 12(2), 87 -100.

Valickas A., Raišienè A. G., Arimavičiūtè, M. (2017) Leadership competences for the excellence of municipalities' strategic management. Journal of International Studies, 10(4), 131-142.

Vlacseková, D., \& Mura, L. (2017). Effect of motivational tools on employee satisfaction in small and medium enterprises. Oeconomia Copernicana, 8(1), 111-130.

Výrostová, E. (2010). Regionálna ekonomika a rozvoj. Bratislava: Iura Edition.

Wehrens, R. (2011). Chemometrics with R. Multivariate Data Analysis in the Natural Sciences and Life Sciences. Heidelberg: Springer.

Yussof, I., \& Kasim, M., Y. (2003) Human Resources Development and Regional Cooperation within BIMP-EAGA: Issues and Future Directions. Asia-Pacific Development Journal, 10(2), 41-56.

Žul'ová, J., Švec, M., \& Madleňák, A. (2018). Personality aspects of the employee and their exploration from the GDPR perspective. Central European Journal of Labour Law and Personnel Management, 1(1), 68 - 77. doi:10.33382/cejllpm.2018.01.05. 